\title{
EARLY RESPONSE OF INFLAMMATORY PROTEINS IN THE STRIATUM AND HIPPOCAMPUS OF NEWBORN PIGLETS FOLLOWING CARDIOPULMONARY BYPASS AND CIRCULATORY ARREST
}

\author{
P. Pastuszko ${ }^{1}$, G.J. Schears ${ }^{2}$, J. Kubin ${ }^{3}$, W.J. Greeley ${ }^{4}$, D.F. Wilson ${ }^{3}$, A. Pastuszko ${ }^{3}$ \\ ${ }^{I}$ Department of Surgery, University of California, San Diego, San Diego, CA, ${ }^{2}$ Department of Anesthesiology \\ and Critical Care, Mayo Clinic, Rochester, MN, ${ }^{3}$ Department of Biochemistry and Biophysics, University of \\ Pennsylvania, ${ }^{4}$ Department of Anesthesiology and Critical Care Medicine, The Children's Hospital of \\ Philadelphia, University of Pennsylvania School of Medicine, Philadelphia, PA, USA
}

Background and aims: Inflammation plays a key role in ischemic brain injury. We examined the levels of select inflammatory proteins in the striatum and hippocampus of newborn piglets in a cardiopulmonary bypass (CPB) and deep hypothermic circulatory arrest (DHCA) ischemia model.

Methods: Piglets were placed on $\mathrm{CPB}$, cooled to $18^{\circ} \mathrm{C}$, subjected to $30 \mathrm{~min}$ of DHCA and $1 \mathrm{hr}$ of low-flow $(20 \mathrm{ml} / \mathrm{kg} / \mathrm{min})$, rewarmed to $37^{\circ} \mathrm{C}$, separated from $\mathrm{CPB}$, monitored for $2 \mathrm{hrs}$ and then striatum and hippocampus were isolated for protein analysis. Protein levels are presented in arbitrary units (mean $\pm \mathrm{SE}$ ).

\section{Results:}

Striatum: CPB/DHCA increased, as compared with sham operated animals, pro-inflammatory cytokines implicated in ischemic brain injury: interleukin $1(365 \pm 12.7$ vs $583 \pm 83, \mathrm{p}<0.047)$ and tumor necrosis factoralpha ( $318 \pm 37$ vs $402 \pm 18, \mathrm{p}<0.05)$; chemotactic cytokines: growth regulated protein (GRO) (226 \pm 16 vs $376 \pm 42, \mathrm{p}<0.02)$, GRO-alpha (178 \pm 16 vs $297 \pm 17, \mathrm{p}<0.001)$ and interleukin-8 (591 \pm 47 vs $728 \pm 40, \mathrm{p}<$ $0.05)$; chemokines: macrophage inflammatory protein-3 (58 18 vs $88 \pm 7, \mathrm{p}<0.05)$ and eotaxin $(107 \pm 7$ vs $164 \pm 17, \mathrm{p}<0.02)$. Vascular endothelial growth factor, potentially protective, was decreased $(25 \pm 5 \mathrm{vs} 11 \pm 3$, $\mathrm{p}<0.05)$.

Hippocampus: There were no significant differences in the above proteins after CBP/DHCA. However, potentially protective proteins, interleukin-10 (338 \pm 18 vs $405 \pm 5, \mathrm{p}<0.02)$ and transforming growth factor beta $(389 \pm 24$ vs $460 \pm 16, \mathrm{p}<0.05)$, were increased.

Conclusions: In piglet model of CBP/DHCA, early response of proteins regulating inflammation in the brain is region-dependent: proteins exacerbating ischemic injury are increased in the striatum, whereas those with potential protective role are increased in the hippocampus.

Acknowledgements: Supported by NIH grant HL58669. 